\title{
Could Russia Utilize Cryptocurrencies in Its Foreign Policy Grand Strategizing?
}

\section{Cryptocurrencies as a Challenge to U.S. Global Hegemony}

Nicholas Ross Smith

\begin{abstract}
Russia, under the stewardship of Vladimir Putin, has arguably taken a number of steps to try and secure a position as a pole in an emerging multipolar world. One step has been to modernize its military and reassert itself globally (evident in its Syria action), while another step has been to try and hasten the decline of the United States (evident in its BRICS cheerleading). It is argued that the latter step is particularly difficult to achieve because the United States still has a significant power advantage over the rest. Additionally, the United States' hegemonic position is further insulated by having the U.S. dollar as the global
\end{abstract}

\footnotetext{
Nicholas Ross Smith, PhD.

University of Nottingham, Ningbo, China

Assistant Professor of International Studies
}

ORCID-0000-0003-1959-0365

E-mail—nrsmith@outlook.co.nz

Address: 199 Taikang East Road, Ningbo 315100, China

This article was initially prepared for the Australasian Association for Communist and PostCommunist Studies, 14th Biennial Conference at Griffith University, January 31, 2019. Many thanks to Milenko Petrovic, Alexander Akimov, Nina Markovic, Maximillian Mayer, Zbigniew Dumienski, and Glenn Diesen for their contributions to the final version of this article. 
reserve currency. However, it is argued that the rise of cryptocurrenciesparticularly with their inherent counter-hegemonic properties-challenges the United States' enviable financial position. It is, therefore, theorized that Russia could utilize cryptocurrencies-either by supporting independent ones or by creating its own - to try and weaken the United States' financial clout in order to hasten its broader decline in international politics.

\section{INTRODUCTION}

The growth of cryptocurrencies, and related technologies such as blockchain, globally has been exponential in the last five years. Russia, to date, has been one of the more enthusiastic countries to have dabbled in this cryptocurrency revolution, both at grassroots and formal levels. While the development of cryptocurrencies has hit some noticeable speed-bumps in the last year, particularly with the significant corrections of the main cryptocurrency coins (such as Bitcoin and Ethereum) in 2018, the technological revolution that these coins represent is here to stay. This article considers the plausibility of Russia using cryptocurrencies-because of their potentially disruptive, counter-hegemonic properties-in its foreign policy grand strategizing, especially regarding the objective of diminishing American hegemony. And while the ability of Russia to utilize cryptocurrencies to achieve foreign policy ends remains murky with particular domestic hurdles, it is, nevertheless, a potential American blind spot at the moment which could be exploited.

This article is developed in four sections. The first section examines Russia’s global foreign policy grand strategy of securing a position as a pole in a future multipolar world. The second section pours cold water on the idea that multipolarity has already emerged in the international system through looking at the United States' various power advantages over the rest, including, crucially, its continued dollar hegemony. The third section forwards an argument that cryptocurrencies (and related technologies) are potentially counter- 
hegemonic and, thus, could challenge the U.S. dollar in the future. The last section, subsequently, evaluates to what extent Russia could utilize cryptocurrencies to challenge the United States by looking at two options: supporting independent cryptocurrencies or creating a state-backed cryptocurrency.

\section{RUSSIA'S GRAND STRATEGY}

One of the clearer tenets of Russia's foreign policy grand strategy, particularly since Vladimir Putin's return as president in 2012, is to secure Russia's position as a pole in a future multipolar world (Diesen and Wood, 2012; Ambrosio, 2017; Smith, 2017). Such an outcome is clearly predicated on two events occurring: the restoration of Russia's credibility as a "global"-as opposed to just a "regional" - great power coupled with the diminishment of American global hegemony.

Regarding the first event, the restoration of Russia's credibility as a global great power has been a major focus for the Kremlin since its unconvincing intervention in Georgia in 2008 (Bryce-Rogers, 2013; Renz, 2014). Although the war lasted a mere five days and resulted in a clear Russian victory, a glaring deficiency (even compared to the Georgians) in "information technology, unmanned aerial vehicles and precision-guided munitions" was exposed (Renz, 2014, p. 65). Vendil Pallin and Westerlund (2009, p. 401) argue that the Georgia conflict demonstrated that Russia's "precision weapons cannot compete with Western versions and its C4ISR capabilities (command, control, communications, computers, intelligence, surveillance and reconnaissance) are in need of upgrading." Shortly after the conflict, Russia's then minister of defense, Anatoly Serdyukov, began an ambitious modernization of its military power with the aim of being 70 percent modernized by 2020 , relative to the $10-15$ percent level of modernization during the Georgian conflict (Renz, 2014). In addition to the modernization of its capabilities, Russia's post-Georgia strategy has also emphasized smaller, more efficient armed forces as well as improved training and education (Bryce-Rogers, 2013). While Russia's modernization plans have been challenged by low oil prices-which hit a nadir in early 2016-and Western sanctions, along with rumored 
infighting between different governmental branches, it has still made noticeable strides (McDermott, 2017). As Putin (2018) recently stated, "Russia's new weaponry is years and even decades ahead of their foreign analogues and has rendered many high-cost-very high-cost, to be frank-foreign systems ineffective and even obsolete."

Despite accusations of hyperbole in the West, it is important to note that some of the fruits of Russia's military modernization have already been demonstrated in its military support for the Assad regime in Syria. Its Syria action is notable because it represents the first time Russia has intervened militarily beyond its self-defined 'Near Abroad' since the fall of the Soviet Union (Trenin, 2016). Up until Putin's decision to support al-Assad in the Syrian civil war in September 2015, Russia had been characterized increasingly as, at best, a regionally focused great power that only had an appetite for undertaking interventions on its borders, such as in Georgia and Ukraine (Aron, 2013; Ikenberry, 2014). In Syria, Russia has been able to help al-Assad turn the tide; going from what appeared to be an imminent defeat to now appearing the most likely victor, although it will most probably remain a protracted conflict for some time (Trenin, 2018.) In late 2017, Bashar al-Assad personally thanked Putin and the Russian people for "Russia's efforts to save our country" (Sanchez, 2017). In addition to its Syria action, Russia has remained vocal on the North Korean nuclear weapons issue and has noticeably increased its nuclear weapons posturing towards the United States-all symptoms of a state attempting to reclaim its global great power credibility.

The second event, the diminishment of American hegemonywhich is necessary to usher in an age of multipolarity - is a far tougher assignment. Nevertheless, Russia has been extremely proactive in its attempts to hasten American decline. Under Putin, Russia has not shied away from challenging the United States' position on global matters at every opportunity (Tsygankov, 2015). This defiance first came to the fore in response to the United States' invasion of Iraq in 2003; after Russia had supported the United States' invasion of Afghanistan in 2001 and its "Global War on Terror." As Ambrosio (2017, p. 153) notes, "the Bush administration's seemingly inexorable march to war changed 
the nature of debate within Russian foreign policy circles," leading to a belief emerging that it was not in Russia's interests to reside in an international system dominated by the United States. More recently, Russia has arguably been the most enthusiastic member of the BRICS grouping-a group of five "emerging powers": Brazil, Russia, India, China, and South Africa. The BRICS group largely came to fruition due to a mutual perception amongst its members that the Americanled international order was unfairly tilted towards American interests (Glosny, 2009). Thus, through undertaking dialogue and promoting cooperation beyond the scope of the multilateral structures put in place by the United States, the BRICS grouping has been very much about challenging the status quo (Govella and Aggarwal, 2011).

Beyond Russia's continued challenging of the United States globally and its "cheerleading" of the BRICS, co-opting China, given its position as a legitimate long-term challenger to the United States, is the most crucial element to Russia's putative desire to bring about a multipolar international system. Fortunately for Putin, China, particularly evident in the evolution of Xi Jinping's grand strategy for China's rise, similarly seems to desire the diminishment of American hegemony (Moore, 2017). Indeed, given that there is more economic interdependenceboth financial and trade-in the Sino-American relationship (albeit under strain due to the ongoing trade war), China's ambition is clearly not as cut and dry as Russia's. While already an economic superpower, China has also taken steps to improve its military capabilities and is taking a more proactive stance on global leadership (Schweller and $\mathrm{Pu}, 2011)$. Importantly, both Putin and Xi seem to be on the same page when it comes to their basic conceptions of international relations; both see sovereignty as supreme and Western liberalism as a product of hegemonic hubris (Acharya, 2017; Diesen, 2017).

\section{THE UNITED STATES' HEGEMONY}

The eventual decline of the United States to a point where it is no longer the global hegemon is generally treated as a fait accompli these days. Terms such as 'post-American world,' 'G-Zero', and 'multipolarity' have gained widespread usage in the mainstream coverage of international 
affairs in recent years (Zakaria, 2008; Bremmer and Roubini, 2011; Layne, 2012). Of course, it is undeniable that the system is transitioning towards multipolarity, although it may experience a few decades of bipolarity first (Schweller, 2018). But the key point is that this is happening at a glacial pace (Smith, 2016). Furthermore, when the main power metrics-military, economic and soft-are examined, the United States' position as the hegemon of international politics seems secure for the foreseeable future.

Regarding military power, the United States is the world's strongest power by a significant margin. In 2017, the United States' military expenditure was $\$ 610$ billion (3.1\% of GDP), almost three times larger than the second highest, China (\$228 billion at $1.9 \%$ of GDP)-Saudi Arabia (not Russia or Britain or France) interestingly, was third with an expenditure of $\$ 69$ billion at 10\% of GDP (SIPRI, no date). Regarding economic power, although China's economic rise over the last two decades has been unprecedented, the United States remains the world's strongest economic power. According to 2017 figures, the United States remains the world's largest economy with a GDP (current \$U.S.) of \$19.4 trillion, ahead of the EU's \$17.3 trillion and China's $\$ 12.2$ trillion while also being less reliant on international trade (27\%) than China (38\%), or the EU (83\%) (World Bank, no date). Lastly, regarding soft power, which is the least tangible of the power measurements examined here, the United States ranks higher than any of its hegemonic challengers. In the 'Soft Power 30' 2017 index, the United States rated as the third most powerful in terms of soft power (behind France and the United Kingdom) with China coming in 25th and Russia 26th (McClory, 2017).

Crucially, on top of its abovementioned power advantage in international politics, the United States also has additional insulation from its hegemonic decline from the continued status of the U.S. dollar as the world's reserve currency. Former French President Valéry Giscard d'Estaing described the hegemony of the American dollar as representing an "exorbitant privilege" to the United States over the rest of the world (Eichengreen, 2011). The premise of this argument was that because the U.S. dollar had a special status as the global reserve 
currency, the United States could not experience a balance of payments crisis as its imports were purchased in its own currency. In other words, it afforded the United States a unique ability to run up a massive current account deficit at an incredibly cheap rate by simply printing more money or issuing debt. Consequently, because of this privilege, the United States' Net International Investment Position (NIIP) has spiraled out of control to the point it is now approaching $-\$ 10$ trillion, easily the world's largest (Bureau of Economic Analysis, no date).

In contrast to the United States' spiraling levels of debt, China has become one of the world's largest creditor states, behind Japan and Germany, with its NIIP reaching $+\$ 1.7$ trillion in 2015 (Steil and Smith, 2017). China's motivations for being a creditor state is that it enables it to influence international trade and finance through offering cheap loans-either to advantage its own companies internationally or to grow ties with resource-rich countries in the Global South (Fukuyama, 2016). However, in doing so, it has had to accept a negative Net Investment Income (NII), unlike Japan and Germany, which had plummeted to $\$ 80$ billion in 2015-the world's worst NII. The problem for China has been that occupying such an unfair position comparatively to the United States-what Steil and Smith call an "exorbitant detriment" - has become increasingly difficult given China's economic wobbles over the past couple of years (Steil and Smith, 2017).

Of course, there are downsides to having the world's reserve currency. For some, the United States' high levels of debt are problematic, not only because of the risk associated with being in so much debt but also because it has propelled an enormous trade deficit. Notably, this trade deficit has been a major concern of Trump's first term in office, leading to the United States adopting a number of ostensibly mercantile policies-most significantly towards China-in an effort to balance its trade (Tankersley, 2018). Furthermore, China's long-held strategy of buying U.S. dollars-it is the world's largest holder of dollar-denominated central bank reserves-gives it some leverage over the U.S. that it can use in times of disagreement (Setser, 2008). Nevertheless, this article argues that the advantages of having the 
world's reserve currency-part of what Zbigniew Dumienski (2018) terms 'fiat power'-still outweigh the disadvantages as it pertains to international political power. This is partly because, as Drezner (2009, p. 53) argues, "the power of credit has been inflated beyond its true worth" and that, against great powers, and especially a superpower, using credit is "of limited use" as a foreign policy tool.

From the perspective of the challengers to the United States' hegemony, there is clearly a perception that diminishing this "exorbitant privilege" is an important component in realizing their grand strategies. China, for instance, has ramped up its efforts to try and level the playing field with the United States in recent years by launching the Belt and Road Initiative (BRI) in 2013 and the Asian Infrastructure Investment Bank (AIIB) in 2014, both of which are components in China's grand strategy to "change the global governance economic order" (Hanlon, 2017). Russia, too, has sought to undermine the United States' international financial position in recent years. For instance, at the 2018 BRICS Business Forum in Johannesburg, South Africa, Putin emphasized the need for more BRICS cooperation in the realm of international finance as "the United States has global economic power due to the dollar being used as the international currency, which makes global countermeasures extremely important now in order to partially move beyond the dollar and create a nondollar economy" (TASS, 2018).

The idea that the United States' privileged financial position, underpinned by its dollar hegemony, is in terminal decline has certainly gained some popularity in the last year or two, partly due to the aforementioned increased focus of China and Russia towards challenging it. However, a similar surge in proclaiming the United States' exorbitant privilege dead occurred after the onset of the global financial crisis in 2007 (Layne, 2012). However, as Fichtner (2017, p. 3) discovered, "contrary to conventional wisdom, Anglo-America's share in financial wealth has increased since the financial crisis" to a point where it "permeates almost every political economy in the world and influences political and economic decision-making." Consequently, a fair assessment is that the United States' dollar hegemony is far more 
resilient than most have expected as it has withstood, to date, both significant external challenges and a global financial crisis. As Norrloff (2014) argues, the collapse of the United States' dollar hegemony cannot happen without a significant shift in the international system-i.e. the emergence of a legitimate challenger.

\section{CRYPTOCURRENCIES AS A DISRUPTIVE, COUNTER-HEGEMONIC TECHNOLOGY}

There is a looming potential challenge to the United States' dollar hegemony (and, gradually, its international primacy) beyond the putative efforts of China and Russia. This challenge does not come from a state, but rather from a stateless, bottom-up technological phenomenon that has emerged in the last ten years: independent cryptocurrencies (Nakamoto, 2008). Concisely, an independent cryptocurrency is a digitalized asset that is "constructed to function as a medium of exchange, premised on the technology of cryptography, to secure the transactional flow, as well as to control the creation of additional units of the currency" (Chohan, 2017). Thus, unlike fiat currencies which rely on central authorities to manage them and keep them secure, independent cryptocurrencies rely on harnessing new and developing (usually decentralized) cryptographic technologies (Narayanan et al., 2016).

The growth of independent cryptocurrencies, even when factoring in recent troubles, has been impressive. Bitcoin's meteoric growth, surpassing the $\$ 10,000$ barrier in 2017 (although it was hovering around $\$ 3000$ as of January 2019), has been called by Dominic Frisby (2017) the "greatest money-making opportunity of our lifetime." Rival cryptocurrencies, such as Ethereum, EOS, Monero, Cardano, and Litecoin (to name but a few), have also experienced similar growth trajectories (although all, like Bitcoin, have recently experienced a prolonged period of deflation). Nevertheless, the relative rise of these coins remains impressive. For instance, even the 10th largest coin, as of January 2019, Bitcoin SV, still had a market capitalization of $\$ 1.3$ billion while Bitcoin continues to lead the way with a market capitalization of $\$ 62.5$ billion (CoinMarketCap, no date). 
What explains this incredible development? Advocates of cryptocurrencies argue that they offer a cheaper, faster, and safer way of transferring funds than conventional methods, which are closely regulated by states. Additionally, they also point to cryptocurrencies being less biased and sounder alternatives to the current, Americanled monetary system which is blighted by low-interest rates and the continuous debasement of the U.S. dollar and other popular international currencies. Cryptocurrencies also harness cuttingedge technologies-such as blockchains-which offer benefits that conventional banking services have yet to adopt. Cryptocurrencies also appeal to some on an ideological level, especially libertarians and anarchists, as they represent a stateless (even anti-state, for some) endeavor (Bashir, Strickland and Bohr, 2016).

Beyond the obvious challenge of cryptocurrencies to conventional "fiat" currencies mentioned above-as well as the potential to undermine the current taxation systems of most states (Dumienski and Smith, 2018) - they also potentially pose a massive challenge to the international political power the United States' derives from its exorbitant privilege of having the dollar hegemony. Buchanan (2013) argues that Bitcoin has a counter-hegemonic potential because it "decentralizes power and the value attributed to it" and "its mining process that makes it inherently inflation and debt free." Thus, as Bitcoin and other similar cryptocurrencies potentially grow and become more prominent in international finance, they will slowly eat away at the United States' centralized financial power, reducing the influence that the U.S.-led financial institutions currently have on the global political economy. Furthermore, it would drastically increase the costs of borrowing for the United States, which would make its currently heavily indebted position untenable, removing any relative advantage it currently has.

Furthermore, as cryptocurrencies increasingly capture the imagination of people, corporations, and states-a process that has been occurring on a truly global scale-the pervading perception that the United States has unbreakable financial power will symbiotically wane. This could help open the floodgates towards, at the very least, 
consideration of adopting a cryptocurrency as the global reserve currency. The flow-on effects of this, from an international power perspective, beyond the aforementioned detriments to its financial clout, would be that the United States would lose some of its ability to exercise effective economic statecraft-such as sanctions, embargos, and the freezing of assets. Also, over time, the U.S. would lose the prestige of being considered the unequivocal global financial hegemon and, thus, lose some of its insulation from the process of broader hegemonic decline.

Of course, independent cryptocurrencies are not without their inherent issues. For instance, whether these coins can develop the capacity to seriously challenge the sheer volume of transactions that the conventional international monetary system can process remains doubtful for some (Claeys, Demertzis andEfstathiou, 2018). In addition, most of the main cryptocurrencies have grown into speculative bubbles that could pop at any moment. Bitcoin, for example, had, at its height, increased over 101,745\% since its inception, whereas in January 2019 it dropped to an increase of 2,545\% (CoinMarketCap, n. d.). The recent struggles of the majority of mainstream cryptocurrencies attest to a less than certain future for these coins.

However, as Dominic Frisby (2017) points out, whatever happens to the current crop of cryptocurrencies, the utility of the technology pioneered by the cryptocurrency boom will remain and continue to develop. Consequently, while many of the independent cryptocurrencies might not survive the problems of lacking capacity, speculative mania, and the increasing crackdown by governments, the ongoing cryptocurrency technological revolution has irrevocably changed currency moving forward and, in theory, has the real potential to undermine the United States' dollar hegemony, and, eventually, its international political hegemony.

\section{CAN CRYPTOCURRENCIES BE WEAPONIZED?}

Given that cryptocurrencies could be seriously damaging, in the long-term, to the United States' power position in international politics, it is reasonable to think that for the countries that seem 
intent on bringing an end to the U.S.-led liberal international order, encouraging the growth of cryptocurrencies might become a tangible policy in the future. This particularly true for Russia which, unlike China, cannot realistically challenge the United States' financial might through conventional means. While the potential for countries like Russia to utilize cryptocurrencies against the United States' privileged international financial position has not been rigorously examined yet, there does seem, in theory, to be two potential ways Russia could utilize cryptocurrencies.

One potential strategy is that Putin could turn Russia into a haven for the independent cryptocurrencies that have taken the world by storm. As discussed earlier, independent cryptocurrencies like Bitcoin arguably have the most counter-hegemonic potential because they are decentralized and anonymous. If a relatively large financial player like Russia were to support independent cryptocurrencies, then their potential to eat away at the United States' centralized financial power would be enhanced. One of the recurring fears in much of the discourse on cryptocurrencies in the United States is their clandestine use. This is because regulating them is incredibly difficult and, to date, has proved practically impossible (see South Korea, for example). Thus, Russia becoming a haven for independent cryptocurrencies would be incredibly hard for the United States to regulate and manage.

The challenge for Russia here is that promoting independent cryptocurrencies could undermine the strict control that financial elites in Russia exert over the economy (the same is true for China, see: de Jonge and de Jonge, 2018). For instance, Russia ranked as "mostly unfree" on the 2018 Index of Economic Freedom, coming 107th out of 186 countries (The Heritage Foundation, 2018). Thus, becoming a safe haven for these largely anonymous and decentralized currencies could be extremely subversive to Russia's tight control of its economy. This possibly explains why Putin, to date, has trodden a cautious line regarding Russia's policy on independent cryptocurrencies. Indeed, the most recent stance in Russia-it is important to note that Russia's stances on independent cryptocurrencies have been prone to wild fluctuations so far-regarding cryptocurrencies is that it should be 
illegal for them to be used "as private money and money surrogates" as only the state-controlled ruble should have that privilege (Chang, 2018). Nevertheless, Putin seems to have a budding personal relationship with the founder of Ethereum, Vitalik Buterin, so it is hard to predict exactly what Russia's eventual position on independent cryptocurrencies will be (del Castillo, 2017).

A second strategy would be for Russia to create its own state-backed cryptocurrency. This is something that Russia has already intimated that it is giving serious thought to. Perhaps Russia has been inspired by one of its friends, Venezuela, which has attempted, albeit wildly unsuccessfully, to issue its own cryptocurrency called the Petro (Al Jazeera, 2018). Indeed, there have been plenty of whispers that a cryptoruble is in the works, with some saying a mid-2019 issue date being a reality (Radio Free Europe, 2017). When discussing the potential use of the emerging cryptocurrency technology with the head of Russia's largest bank Sberbank, German Gref, Putin stated that "the Stone Age did not end due to the lack of stones, but because new technologies appeared," thus "we need to take the maximum advantage of these factors [...] to guarantee this progress into the future" (Zuckerman, 2018). In this vein, perhaps Russia's most ambitious suggestion, to date, is the idea of a BRICS-backed cryptocurrency as "a good alternative to the dollar and other settlement methods" (Suberg, 2017). Ultimately, if China were keen to cooperate, then something of this magnitude would certainly give the United States reasons for concern.

The problem with creating a state-backed (or a BRICS-backed) coin to challenge the U.S. dollar is that state-backed cryptocurrencies lose much of the counter-hegemonic potential of independent ones. To this end, if state-backed cryptocurrencies win out over independent ones, then rather than systemic revolution, something more akin to systemic evolution will occur as the underlying financial structures (i.e., the pervading fiat power) will not alter that radically. Also, whether a Russia or BRICS cryptocurrency could garner enough international credibility to challenge the U.S. dollar is highly doubtful. Furthermore, from a technological standpoint, state-controlled cryptocurrencies, given that they would have to be centralized to a certain degree, are 
also likely far more vulnerable to cybercrime and, of course, cyber warfare (Gardner, 2016). This would make them potentially an easier target than independent cryptocurrencies for the United States to counteract. Though, if they were backed by the combined strength of Russia and China then the United States' options would probably be limited anyhow.

Ultimately, whether cryptocurrencies can be utilized in a way that challenges the United States' financial supremacy remains murky. Further to this, one cannot discount the United States' ability to counteract any threat from cryptocurrencies. The United States remains the world's pre-eminent technological power and surely could, if it decided to get into the game, turn itself into a world leader with regard to cryptocurrency technology. However, as it currently stands, the United States does not seem to perceive any strategic threat regarding either independent or state-backed cryptocurrencies; the U.S. is more concerned about financial issues and their clandestine use. Thus, there is something of a window of opportunity for Russia and, potentially-if relations with the United States continue to sour-China. If one accepts that the lynchpin of the United States' international primacy is its privileged international financial position, and a weak spot of its privileged international financial position is the rise of cryptocurrencies, then cryptocurrencies could be "the straw that breaks the camel's back" in speeding up the transition from the current system of American primacy towards something more akin to multipolarity.

\section{References}

Acharya, A., 2017. After liberal hegemony: the advent of a multiplex world order. Ethics \& International Affairs, 31(3), pp. 271-285.

Ambrosio, T., 2017. Challenging America's global preeminence: Russia's quest for multipolarity. Abingdon: Routledge.

Aron, L., 2013. The Putin doctrine. Foreign Affairs [online]. Available at: $<$ https://www.foreignaffairs.com/articles/russian-federation/2013-03-08/ putin-doctrine $>$ [Accessed 3 October 2018]. 
Bashir, M., Strickland, B. and Bohr, J., 2016. What motivates people to use bitcoin? In: Spiro, E. and Ahn, Y.Y. (eds). Social informatics. Cham: Springer.

Bremmer, I. and Roubini, N., 2011. AG-Zero world-the new economic club will produce conflict, not cooperation. Foreign Affairs, 90(2), pp. 2-7.

Bryce-Rogers, A., 2013. Russian military reform in the aftermath of the 2008 Russia-Georgia war. Demokratizatsiya, 21(3), pp. 339-368.

Buchanan, J., 2013. Bitcoin vs. dollar hegemony. E-International Relations Studies [online]. Available at: <http://www.e-ir.info/2013/09/16/bitcoin-vsdollar-hegemony/> [Accessed 22 January 2018].

Bureau of Economic Analysis, n. d. U.S. net international investment position. U.S. Department of Commerce [online]. Available at: <https://www.bea.gov/ newsreleases/international/intinv/intinvnewsrelease.htm $>$ [Accessed 21 June 2018].

del Castillo, M., 2017. Vladimir Putin and Vitalik Buterin discuss ethereum "opportunities." CoinDesk [online]. Available at: <https://www.coindesk. com/vladimir-putin-vitalik-buterin-discuss-ethereum-opportunities-recentforum/> [Accessed 24 May 2018].

Chang, S., 2018. Russia to criminalize bitcoin use as money substitute: Putin to roll out laws. Investopedia [online]. Available at: $<$ https://www.investopedia. $\mathrm{com} /$ news/russia-criminalize-bitcoin-use-money-substitute-putin-roll-outlaws/> [Accessed 24 May 2018].

Chohan, U. W., 2017. Cryptocurrencies: a brief thematic review. SSRN [online]. Available at: <http://dx.doi.org/10.2139/ssrn.3024330> [Accessed 27 September 2018].

Claeys, G, Demertzis, M and Efstathiou, K., 2018. Cryptocurrencies and monetary policy. Publications of the European Union. Available at: https:// publications.europa.eu/en/publication-detail/-/publication/3d806470-b4a811e8-99ee-01aa75ed71a1/language-en/format-PDF [Accessed 04 March 2019].

CoinMarketCap, n. d. Cryptocurrency market capitalizations, CoinMarketCap [online]. Available at: <https://coinmarketcap.com/> [Accessed 10 February 2019].

de Jonge, M. and de Jonge, D., 2018. A Brief overview on China and cryptocurrency. Ningbo Economic Review, 1(1), pp. 33-35.

Diesen, G., 2017. Russia's geoeconomic strategy for a Greater Eurasia. London: Routledge. 
Diesen, G. and Wood, S., 2012. Russia's proposal for a new security system: confirming diverse perspectives. Australian Journal of International Affairs, 66(4), pp. 450-467. doi: 10.1080/10357718.2012.692530.

Drezner, D. W., 2009. Bad debts: assessing China's financial influence in great power politics. International Security, 34(2), pp. 7-45.

Dumienski, Z., 2018. Email correspondence with the author.

Dumienski, Z. and Smith, N. R., 2018. The potential of cryptocurrencies to transform our taxation systems for the better. Global Policy [online]. Available at: <https://www.globalpolicyjournal.com/blog/02/02/2018/ potential-cryptocurrencies-transform-our-taxation-systems-better $>$ [Accessed 2 June 2018].

Eichengreen, B., 2011. ExorbitantpPrivilege: the rise and fall of the dollar and the future of the international monetary system. Oxford: Oxford University Press.

Fichtner, J., 2017. Perpetual decline or persistent dominance? Uncovering Anglo-America's true structural power in global finance. Review of International Studies, 43(1), pp. 3-28.

Frisby, D., 2017. Bitcoin has broken the $\$ 10,000$ barrier-and this run can go further. The Guardian [online]. Available at: <https:/www.theguardian.com/ commentisfree/2017/nov/29/bitcoin-broken-10000-dollar-barrier-frenzybubble> [Accessed 22 January 2018].

Fukuyama, F., 2016. Exporting the Chinese model. Project Syndicate [online]. Available at: $<$ https://www.project-syndicate.org/onpoint/china-one-belt-oneroad-strategy-by-francis-fukuyama-2016-01?barrier=accesspaylog $>$ [Accessed 25 May 2018].

Gardner, R., 2016. Centralization proves to be a security flaw for cryptocurrencies. Finance Magnates [online]. Available at: <https://www.financemagnates.com/cryptocurrency/bloggers/centralization-proves-security-problemcryptocurrencies/> [Accessed 22 January 2018].

Glosny, M. A., 2009. China and the BRICs: a real (but limited) partnership in a unipolar world. Polity, 42(1), pp. 100-129.

Govella, K. and Aggarwal, V. K., 2011. Responding to a resurgent Russia: Russian policy and responses from the European Union and the United States. New York: Springer. 
Hanlon, R. J., 2017. Thinking about the Asian Infrastructure Investment Bank: Can a China-led Development Bank improve sustainability in Asia? Asia \& the Pacific Policy Studies, 4(3), pp. 541-554.

Ikenberry, G. J., 2014. The illusion of geopolitics: the enduring power of the liberal order. Foreign Affairs, 93(3), pp. 80-86.

Al Jazeera, 2018. What is Venezuela's new petro cryptocurrency? Al Jazeera [online]. Available at: <https://www.aljazeera.com/news/2018/02/venezuelapetro-cryptocurrency-180219065112440.html> [Accessed: 24 May 2018].

Layne, C., 2012. This time it's real: the end of unipolarity and the Pax Americana. International Studies Quarterly, 56(1), pp. 203-213.

McClory, J., 2017. The soft power 30: a global ranking of soft power. Portland: Portland Communications.

McDermott, R., 2017. Shoigu promotes Russia's 'effective army' plans to 2025. The Jamestown Foundation [online]. Available at: <https://jamestown.org/ program/shoigu-promotes-russias-effective-army-plans-2025/> [Accessed: 24 May 2018].

Moore, G. J., 2017. Avoiding a Thucydides trap in Sino-American relations (... and 7 reasons why that might be difficult). Asian Security, 13(2), pp. 98-115.

Nakamoto, S., 2008. Bitcoin: a peer-to-peer electronic cash system [online]. Available at: <https://bitcoin.org/bitcoin.pdf $>$ [Accessed 03 February 2019].

Narayanan, A. et al., 2016. Bitcoin and cryptocurrency technologies: a comprehensive introduction. Princeton University Press.

Norrlof, C., 2014. Dollar hegemony: a power analysis. Review of International Political Economy, 21(5), pp. 1042-1070.

Putin, V., 2018. Meeting on armed forces development. President of Russia [online]. Available at: <http://en.kremlin.ru/events/president/news/57498> [Accessed 24 May 2018].

Radio Free Europe, 2017. Russia's Central Bank considering cryptocurrency within EEU, BRICS. Radio Free Europe [online]. Available at: <https://www. rferl.org/a/russia-central-bank-consider-cryptocurrency-eeu-brics/28943879. html $>$ [Accessed 22 January 2018].

Renz, B., 2014. Russian military capabilities after 20 years of reform. Survival, 56(3), pp. 61-84.

Sanchez, R., 2017. Bashar al-Assad thanks Putin for 'saving our country' as Russian leader prepares for talks on ending Syrian war. The Telegraph [online]. 
Available at: <https://www.telegraph.co.uk/news/2017/11/21/bashar-al-assadsays-ready-syria-peace-talks-rare-meeting-vladimir/> [Accessed 24 May 2018].

Schweller, R., 2018. Opposite but compatible nationalisms: a neoclassical realist approach to the future of U.S.-China relations. The Chinese Journal of International Politics, 11(1), pp. 23-48.

Schweller, R. L. and $\mathrm{Pu}, \mathrm{X} ., 2$ 2011. After unipolarity: China's visions of international order in an era of U.S. decline. International Security, 36(1), pp. $41-72$.

Setser, B., 2008. Sovereign wealth and sovereign power: the strategic consequences of American indebtedness. New York: Council on Foreign Relations.

SIPRI, n. d. SIPRI Military Expenditure Database [online]. Available at: <https:// www.sipri.org/databases/milex> [Accessed 5 December 2018].

Smith, N. R., 2016. EU-Russian Relations and the Ukraine Crisis. Cheltenham: Edward Elgar.

Smith, N. R., 2017. What the West can learn from rationalizing Russia's action in Ukraine. Orbis, 61(3), pp. 354-368.

Steil, B. and Smith, E., 2017. China's exorbitant detriment, mirror image of America's exorbitant rivilege, is costing it dearly. Council on Foreign Relations [online]. Available at: $<$ https://www.cfr.org/blog/chinas-exorbitant-detrimentmirror-image-americas-exorbitant-privilege-costing-it-dearly> [Accessed 21 June 2018].

Suberg, W., 2017. BRICS to discuss cryptocurrency as alternative to national currencies. Cointelegraph [online]. Available at: <https://cointelegraph.com/ news/brics-to-discuss-cryptocurrency-as-alternative-to-national-currencies $>$ [Accessed 24 May 2018].

Tankersley, J., 2018. Trump hates the trade deficit. Most economists don't. The New York Times [online]. Available at: <https://www.nytimes.com/2018/03/05/ us/politics/trade-deficit-tariffs-economists-trump.html> [Accessed 24 May 2018].

TASS, 2018. Press review: BRICS challenges U.S. dollar hegemony and exminister hails Russia-Israel ties. TASS [online]. Available at: <http://tass.com/ pressreview/1015026> [Accessed 17 August 2018].

The Heritage Foundation, 2018. 2018 Index of Economic Freedom [online]. Available at: <https://www.heritage.org/international-economies/ commentary/2018-index-economic-freedom> [Accessed 10 February 2019]. 
Trenin, D., 2016. The revival of the Russian military: how Moscow reloaded. Foreign Affairs, 95(3), p. 23.

Trenin, D., 2018. The new Cold War is boiling over in Syria. Foreign Policy [online]. Available at: <http://foreignpolicy.com/2018/04/14/the-new-coldwar-is-boiling-over-in-syria/> [Accessed 26 April 2018].

Tsygankov, A., 2015. Vladimir Putin's last stand: the sources of Russia's Ukraine policy. Post-Soviet Affairs, 31(4), pp. 279-303.

Vendil Pallin, C. and Westerlund, F., 2009. Russia's war in Georgia: lessons and consequences. Small Wars \& Insurgencies, 20(2), pp. 400-424.

World Bank, n. d. Data [online]. Available at: <http://data.worldbank.org/>.

Zakaria, F., 2008. The post-American world. New York: W. W. Norton \& Company.

Zuckerman, M. J., 2018. Without mentioning Blockchain, Putin says that Russia must stay ahead in technology. Cointelegraph [online]. Available at: <https:// cointelegraph.com/news/without-mentioning-blockchain-putin-says-thatrussia-must-stay-ahead-in-technology> [Accessed 24 May 2018]. 